\title{
God and the Playpen: On the Feasibility of Morally Better Worlds
}

\author{
Cheryl K. Chen
}

check for updates

Citation: Chen, Cheryl K.. 2021. God and the Playpen: On the Feasibility of Morally Better Worlds. Religions 12: 266. https://doi.org/10.3390/ rel12040266

Academic Editor: James Sterba

Received: 12 March 2021

Accepted: 7 April 2021

Published: 12 April 2021

Publisher's Note: MDPI stays neutral with regard to jurisdictional claims in published maps and institutional affiliations.

Copyright: (C) 2021 by the author. Licensee MDPI, Basel, Switzerland. This article is an open access article distributed under the terms and conditions of the Creative Commons Attribution (CC BY) license (https:// creativecommons.org/licenses/by/ $4.0 /)$.
Department of Philosophy, Harvard University, Cambridge, MA 02138, USA; ckchen@fas.harvard.edu

\begin{abstract}
According to the free will defense, God cannot create a world with free creatures, and hence a world with moral goodness, without allowing for the possibility of evil. David Lewis points out that any free will defense must address the "playpen problem": why didn't God allow creatures the freedom required for moral goodness, while intervening to ensure that all evil-doing is victimless? More recently, James Sterba has revived the playpen problem by arguing that an omnipotent and benevolent God would have intervened to prevent significant and especially horrendous evil. I argue that it is possible, at least, that such divine intervention would have backfired, and that any attempt to create a world that is morally better than this one would have resulted in a world that is morally worse. I conclude that the atheologian should instead attack the free will defense at its roots: either by denying that the predetermination of our actions is incompatible with our freely per-forming them, or by denying that the actual world — a world with both moral good and evil—is more valuable than a world without any freedom at all.
\end{abstract}

Keywords: problem of evil; free will defense; Alvin Plantinga; David Lewis; James Sterba; Molinism; Open Theism; theological compatibilism; Hugh McCann; J.L. Mackie

\section{Introduction}

How is the evil that exists in this world consistent with the existence of an omniscient, omnipotent, and benevolent God? This is the "logical problem of evil." Alvin Plantinga sets out to solve it by describing a possible scenario in which God and evil co-exist (Plantinga 1974, pp. 24-28). In order for our actions to be morally good, we have to perform those actions freely. But if we are genuinely free, then we are also capable of performing morally evil acts. God cannot, therefore, create a world with free creatures, and hence a world with moral goodness, without allowing for the possibility of evil. While there are possible worlds with free creatures who never do anything wrong, such morally perfect worlds may not in fact be actualizable by God. Not all possible worlds are feasible worlds. ${ }^{1}$ It is possible that any attempt to actualize a world with free creatures would result in a world in which those creatures commit at least some morally wrong acts (Plantinga 1974, pp. 188-89). But a world containing free creatures who do both good and evil things is better and more valuable than a world without freedom that does not allow for the possibility of any moral good whatsoever (Plantinga 1974, pp. 166-67).

David Lewis points out that any free will defense must address the "playpen problem" (Lewis 1993, p. 155). Perhaps free creatures will commit at least some evil acts no matter what. But an omnipotent God has the power to prevent the causal consequences of evildoing (Lewis 1993, p. 154). So why didn't God put each free creature in a playpen, so to speak, to ensure that all evil is victimless? This would allow us the freedom required for moral goodness, while eliminating the suffering that results from wrongdoing. James Sterba has revived the playpen problem in his recent book, Is a Good God Logically Possible?

1 The term "feasible world" was coined by Thomas Flint. A world is feasible just in case it is a member of the galaxy of worlds determined by the true creaturely world-type (Flint 1998, p. 51), i.e., the type of world God could actualize given the true counterfactuals of freedom (Flint 1998, p. 48). 
(Sterba 2019). Sterba argues that God has a moral obligation to protect the kinds of political freedoms that would ideally be preserved in a just state, such as the freedom from assault, or the freedom to pursue a decent life for oneself (Sterba 2019, pp. 14-15). This requires intervention to prevent - or at least mitigate the consequences of- the horrendous evils that would undermine such freedoms. In effect, God should limit the freedom of those who would commit such evils by confining them to a playpen. The fact that evil-doers are clearly not so confined is incompatible with the existence of an omnipotent and benevolent God.

I will argue that if morally perfect worlds are out of God's reach, then so is the playpen. The upshot of the free will defense is that this world may be among the best worlds God was in a position to actualize. I conclude that the atheologian should instead attack the free will defense at its roots: either by denying that the predetermination of our actions is incompatible with our freely performing them, or by denying that the actual world-a world with both moral good and evil-is more valuable than a world without any freedom at all.

\section{Two Versions of the Playpen}

After introducing the playpen problem, Lewis goes on to propose a possible solution. The reason God did not put free creatures in playpens is because freedom is only significant when something is at stake. The significance of freedom depends, not only on the "good or evil intrinsic character" of our actions, but also on the good or bad outcomes that follow from them (Lewis 1993, p. 154). Lewis is ambivalent about this solution, insofar as it values the significance of Stalin's freedom over the well-being of his prisoners in the Gulag. But he also thinks it will do for the purpose of a defense, and that in any case, it is where the free will defense will inevitably lead (Lewis 1993, p. 155).

As Lewis imagines the playpen, God arranges it so that all evil is victimless. No matter what anyone does, no one suffers as a result. Now Sterba allows that if God were always to intervene then "the freedom we would be left with would hardly be worthy of the name" (Sterba 2019, p. 52). If all evil were victimless, then we would lack the conditions required for "soul-making" 2 (Sterba 2019, pp. 52-53). The acquisition of the virtues requires that we face challenging situations. We cannot become virtuous if confined to Lewis's playpen. But Sterba thinks there is nevertheless room for a less extreme version of the playpen. "Playpen freedom," he says, "is a problem only where freedom is constrained too much" (Sterba 2019, p. 52). In Sterba's playpen, our freedom is appropriately constrained. God intervenes only when the consequences of an evil act are, in Sterba's words, "significant and especially horrendous" (Sterba 2019, p. 53). This is because those significant and especially horrendous consequences interfere with the freedoms of victims.

Here it will be helpful to distinguish, as Michael Almeida does in his review of Sterba's book, between political freedom and metaphysical freedom (Almeida 2020, p. 246). Metaphysical freedom is the freedom of choice we must have in order for our actions to count as morally significant. This is the notion of freedom at play in the free will defense. Political freedoms, on the other hand, are fundamental rights protected by a just state, such as the freedom from assault, or the freedom to pursue a certain standard of living. Sterba contends that political freedoms are more important, and therefore worth protecting even if it means restricting metaphysical freedom, at least when it comes to especially horrendous evil (Sterba 2019, p. 29). (Here Sterba seems to share the discomfort Lewis feels about Stalin and the Gulag: is the significance of Stalin's freedom more significant than the freedom of his prisoners?) We expect a just state to restrict the freedom of would-be wrongdoers, say by preventing assaults, to protect the political freedoms of its citizens (Sterba 2019, pp. 12-14). If this is what we would expect of a just state, then we should expect the same of God. An omnipotent and benevolent God would have prevented the significant and horrendous consequences of evil acts. The fact that we are not confined to Sterba's playpen is inconsistent with God's existence.

2 The concept of a "soul-making" theodicy is originally due to John Hick (1981). 


\section{Plantinga's Reply}

While Plantinga does not address the playpen problem explicitly, he does argue for the possibility that God cannot create a world that is morally better than the actual world (Plantinga 1974, pp. 190-91). If successful, this would effectively solve the playpen problem. After all, the playpen problem assumes two things: first, that the playpen worldthough morally imperfect-is still morally better than the actual world, and second, that the playpen world was within God's power to create. This means that if morally better worlds had been out of God's power to create, then so was the playpen world.

Plantinga's treatment of morally better worlds follows closely his treatment of morally perfect worlds. Remember that a morally perfect world is a world with free creatures who always choose the good. Plantinga begins by assuming that God cannot "strongly actualize" such a world, in the sense of directly causing it to be actual. God cannot directly cause free agents to choose the good, because in doing so their so-called "choices" would not be free after all (Plantinga 1974, p. 171). To actualize a morally perfect world, God must do so indirectly or "weakly" by relying on "counterfactuals of freedom": truths about what free agents would do in various circumstances (Plantinga 1974, pp. 172-73). For example, God cannot strongly actualize Curley's rejection of Smedes's bribe. But suppose God knows that Curley would freely reject the bribe if Smedes is sweating when he makes the offer. Then God can weakly actualize Curley's rejection of the bribe by causing a heatwave in Boston on the day of their meeting. More generally, God is able to weakly actualize a world, $\mathrm{W}$, just in case the counterfactuals of freedom are such that $\mathrm{GT} \rightarrow \mathrm{W}^{3}$, where $\mathrm{T}$ includes everything God strongly actualizes in W. But what if, for any morally perfect world, it is not the case that GT $\rightarrow$ W? Plantinga argues that God would be in that position in the event that all creaturely essences suffer from transworld depravity. ${ }^{4}$ In that case, God would have been unable to actualize a world with free creatures who always choose the good. No matter what free creatures God creates, and no matter what the circumstances, those creatures would inevitably go wrong in one way or another (Plantinga 1974, pp. 188-89).

It should be clear how to apply this machinery to the case of morally better worlds. Let $\mathrm{W}^{*}$ be a possible world that is morally better than the actual world, and let $\mathrm{T}$ include everything God strongly actualizes in $\mathrm{W}^{*}$. Suppose that one of the creatures in $\mathrm{W}^{*}$ freely performs some action, A. But suppose also that it is true of this creature that if God were to strongly actualize T, then the creature would not have performed A. In that case, God would not have been able to actualize $\mathrm{W}^{*}$. To actualize $\mathrm{W}^{*}$, God would first need to strongly actualize $\mathrm{T}$, which would result in a world other than $\mathrm{W}^{*}$. It would then be false that GT $\rightarrow$ $\mathrm{W}^{*}$. Now suppose the same is true of every world that is morally better than the actual world. Then God would not be able to actualize any world that is morally better than this one (Plantinga 1974, p. 191). Since what we are supposing is at least possible, it follows that the existence of an omnipotent and benevolent God is compatible with the amount of moral evil that actually exists in the world. While the actual world is not the best of all possible worlds, it could be among the best of all feasible worlds.

Here is the crucial point, and one which, as far as I am aware, Plantinga does not himself emphasize. Suppose that the true counterfactuals of freedom are such that, for any morally better world, $\mathrm{W}^{*}$, it is false that GT $\rightarrow \mathrm{W}^{*}$. Then, if God were to attempt to actualize a morally better world by strongly actualizing $\mathrm{T}$, the result would be, not $\mathrm{W}^{*}$, but rather a world that is morally worse than the actual world. Any attempt to create a world that is morally better than this one would result in a world that is morally worse. Let

3 This is shorthand for "If God were to actualize T, then W would have been actual".

4 Plantinga defines transworld depravity as follows: "An essence E suffers from transworld depravity if and only if for every world W such that E entails the properties significantly free in $\mathrm{W}$ and always does what is right in $\mathrm{W}$, there is a state of affairs $\mathrm{T}$ and an action $\mathrm{A}$ such that (1) T is the largest state of affairs God strongly actualizes in W, (2) A is morally significant for E's instantiation in W, and (3) if God had strongly actualized T, E's instantiation would have gone wrong with respect to A" (Plantinga 1974, p. 188). Following Otte (Otte 2009), Sterba notes that Plantinga does not actually need to assume that it is possible that every creaturely essence has transworld depravity; instead, it is enough to assume that, for any morally perfect world, if God were to strongly actualize T, then at least one creature would perform at least one wrong act (Sterba 2019, p. 25). 
us use the term "degenerate" to describe this unfortunate combination of counterfactuals of freedom.

The possibility of degeneracy has important implications for the picture of divine intervention at work in Sterba's playpen. Sterba appeals to the 1998 murder of Matthew Shephard as an example of a significant and especially horrendous evil that an omnipotent and benevolent God should have intervened to prevent. God could have easily prevented this hate crime, according to Sterba, by causing the assailants' car to have a flat tire as they were leaving the parking lot (Sterba 2019, p. 21). Consider the possible world, $W^{*}$, in which God does exactly that. In $W^{*}$, the hate crime is averted. Keeping everything else the same, $W^{*}$ is morally better than the actual world. Now the flat tire on the assailants car is included in the T for that world. It is among the states of affairs that God strongly actualizes in $W^{*}$. If the true counterfactuals of freedom are degenerate, then if God were to actualize $\mathrm{T}$, the result would not be $\mathrm{W}^{*}$, but rather a different world that would be worse, not better, than the actual world. God's intervention would not result in a morally better world after all.

Sterba does acknowledge that God's intervention could potentially result in greater evils. Sterba imagines a scenario in which Matthew Shephard survives only to go on to commit horrendous evil acts of his own. In that case, Sterba thinks the appropriate solution is for God to intervene once again to prevent those further evils (Sterba 2019, pp. 21-22). Sterba does not seem to recognize, however, that this second intervention would be no more successful than the first, at least if the desired outcome is to actualize a world that is morally better than the actual world. The same reasoning applies: any additional interventions would also be included in $\mathrm{T}$, and if the true counterfactuals of freedom are degenerate, then God's strong actualization of T would result in a world that is morally worse than the actual world. The limited divine intervention in Sterba's playpen would not do the job: the only way for God to prevent horrendous evil would be to deny creatures any significant freedom whatsoever.

Sterba argues that God's failure to intervene would be a violation of the Pauline Principle: the principle that "we should never do evil that good may come of it" (Sterba 2019 , p. 49). While the principle speaks only of doing evil, Sterba claims that when the evil is significant and easily preventable, permitting evil is morally equivalent to performing it (Sterba 2019, p. 51). Moreover, he thinks God's failure to prevent significant evil does not fall under the three standard exceptions to the principle: the evil is not "trivial," it is not "easily reparable," and it is not "the only way to prevent a far greater harm to innocent people" (Sterba 2019, pp. 49-50). I am suggesting that, if the true counterfactuals of freedom are degenerate, God's failure to prevent significant evil would then be an exception to the Pauline Principle. Any attempt on God's part to prevent horrendous evil-or at least any attempt that leaves some creaturely freedom intact-would result in even more evil. So permitting evil would, in fact, be the only way to prevent far greater harm to innocent people.

At this point it would be worthwhile to revisit Lewis's version of the playpen. Recall that in Lewis's playpen, all evil is victimless: God severs the causal connection between the evil acts we perform and the suffering that would otherwise result. God cannot directly control what choices we make, if those choices are to be genuinely free. But God can control their causal consequences. God cannot prevent Stalin from condemning prisoners to the Gulag (at least while preserving Stalin's freedom). But God can fix it so the prisoners escape unscathed. God can even make sure Stalin never discovers the chronic inefficacy of his evil-doing. The result would be a world with free creatures, but without any of the concomitant suffering. As we saw earlier, both Sterba and Lewis himself dismiss this version of the playpen. For Lewis, freedom is significant only if something is at stake. For Sterba, a world with no suffering would lack the challenges required for soul-making. But now that we have seen that Sterba's version of the playpen is possibly not feasible, Lewis's playpen might not look so bad after all. The problem with Sterba's playpen is that God's intervention is only partial: God allows some evil acts to have their intended 
consequences, intervening only when those consequences are especially horrendous. We have seen that if the true counterfactuals of freedom are degenerate, God cannot prevent horrendous suffering unless the intervention is total. One way to do this is to deny creatures any freedom whatsoever. But another way is to allow creatures to choose freely, but to sever the causal connections between those choices and any suffering that would otherwise follow. That is, to make all evil victimless.

If the true counterfactuals of freedom are degenerate, Lewis's playpen-unlike Sterba's-may still be feasible. It would not, however, be morally better than the actual world. A world with victimless evil and some moral goodness would arguably be better, if we ignore for the moment Sterba's concerns about soul-making. But why think God's interventions would result in a world with any moral goodness at all? It may be that if God were to intervene to make all evil victimless, everyone would always choose wrongly. It may be that any intervention to prevent suffering would result in a world with creatures who make even more morally repugnant (albeit victimless) choices. The free will defense begins with the assumption that a world with no free creatures, and no opportunities for moral goodness, is less valuable than a world with free creatures who perform both good and evil acts. The entire point of endowing creatures with free will is to allow for the possibility of moral goodness. If a world with neither good nor evil is worse than the actual world, then certainly a world with only victimless evil would be no better.

\section{Open Theism and the Playpen}

Plantinga's solution to the playpen problem, as with his free will defense, depends on the Molinist doctrine of "middle knowledge": the view that counterfactuals of freedom guide and constrain God's creative activity (Adams 1977, p. 112). But Molinism is not without its detractors. Some, like Robert Adams, argue that counterfactuals of freedom cannot be true, because there is nothing that grounds their truth. Ordinary counterfactuals are typically grounded in laws of nature and initial conditions. 'If I were to drop a piece of chalk on the floor, then it would break' is true, if it is, in virtue of the law of gravity, the composition of the chalk, the hardness of the floor, etc. But these sorts of facts cannot ground counterfactuals of freedom, since free actions are not causally determined. The fact that Curley would accept (or reject) Smedes's bribe cannot, therefore, be true in virtue of Curley's character, since Curley's character does not causally determine Curley's actions (Adams 1977, p. 111). Adams concludes that God has no "middle knowledge" about what free creatures would do, and must instead make do with knowledge of what free creatures will probably do (Adams 1977, p. 111). Curley's character makes it more likely that he will accept bribes in certain circumstances and not others, but if Curley is a free agent, there is no fact of the matter what he would do in advance of his doing it.

Open Theists, convinced by this reasoning, believe God does not know for certain how we will act, or how we will respond to divine intervention. While God's creative activity can still be guided by knowledge of what we will probably do, God must inevitably assume some degree of risk with the decision to endow us with libertarian free will (Hasker 2004, chp. 8). This picture of divine providence depicts God as a deity who responds to our actions in real time, rather than one who plans out every detail of creation in advance (Hasker 2004, p. 118). Perhaps it is here that the playpen problem could get a foothold. Even if God did not know ahead of time what horrendous evils free creatures would commit, God still had knowledge of these atrocities as they were occurring, and presumably had the power to nip them in the bud. God might not have known what Matthew Shepherd's assailants would do beforehand. But God could have at least intervened once the assault was in progress. After all, if armed police officers had come upon the scene, we would have expected them to intervene and put a stop to it immediately. Failure to intervene in such circumstances would have been a moral outrage. So why not hold God to the same standard?

Tempting as this line of reasoning may be, the Open Theist could respond as follows. Even if there are no counterfactuals about how we would behave in various circumstances, 
the Open Theist admits to facts about how we will probably behave (Flint 1998, p. 97). And it is possible that these facts are similarly degenerate: it is possible that any time God intervenes to put a stop to some horrendously evil act, the probable result is something even more horrendous. It could be that any attempt on God's part to make the world morally better will likely result in a world that is morally worse. Faced with such odds, the most reasonable course of action might be for God to refrain from intervening altogether.

One could object that this kind of degeneracy is preventable if God has control over the characters of the creatures God decides to create. That way God can control how those creatures will probably behave. Of course, this does not guarantee that no one will ever commit evil acts, since again we are assuming that our actions are not causally determined by our characters. But it could, on the face of it, avoid degeneracy if God creates agents that will probably choose the good, even though it is always possible for them to go astray. In that case, God could have created creatures who would probably choose the good, with the aim to intervene in the unlikely event that one of these creatures acts out of character and attempts to commit a horrendously evil act. And if all creatures were such that they would probably choose the good, God's occasional intervention would not likely result in further, or worse, evils. So perhaps a morally better world had been open to God after all.

However, even if we grant that God had power over our characters, so long as our characters do not determine our free actions, it is still possible that a morally better world has been out of God's reach. To see why, suppose God did in fact create free creatures in such a way that they would probably choose the good. As it happens, God turned out to be spectacularly unlucky. Despite the odds, many of God's creatures over the course of history have acted out of character and committed evil acts. Moreover, whenever God attempted to intervene to prevent some horrendous evil from occurring, the result was some other equally horrendous, or possibly even more horrendous, evil. Again, these evil acts may have been out of the evildoers' character, and as a result they were exceedingly improbable. But they happened nevertheless. The only way God could have prevented the amount of evil that has occurred throughout history is by putting an end to creaturely freedom altogether. While this scenario is farfetched, it is enough to solve the logical problem of evil. To solve the logical problem, we need only a defense, not a theodicy.

In sum, both Molinism and Open Theism have the resources to address the playpen problem. Molinists can appeal to degenerate counterfactuals of freedom to argue that is possible that a morally better world would have been out of God's reach. And while Open Theists cannot appeal to degenerate counterfactuals, they can appeal to degenerate facts: it may be that all of God's past interventions resulted in evils more horrendous than those that God was trying to prevent. That could be why a morally better world has so far been out of God's reach. Either way, it is possible that the only way to achieve a world that has less evil than this one is to create a world without any free creatures whatsoever.

\section{A Better Strategy}

This is not to say that I am entirely sympathetic with the free will defense as a response to the logical problem of evil. My point is that the playpen problem grants too much. To begin with, the playpen problem does not take issue with theological incompatibilism: the view that divine determination of our actions is incompatible with our performing those actions freely. The free will defense assumes that God cannot directly control the free performances of actions. The Molinist and the Open Theist disagree about whether God can indirectly control some of our actions by making use of counterfactuals of freedom. But they both agree that God cannot directly determine how we will act, at least if those actions are to be genuinely free. Without this assumption, the free will defense is a nonstarter, since the atheologian could then ask why God did not, in Mackie's words, make us "freely choose the good" (Mackie 1955, p. 209). ${ }^{5}$ The kind of divine intervention we find

5 I am indebted to Gregory Kristof for convincing me that discussions of the free will defense have not paid sufficient attention to the assumption of theological incompatibilism (Kristof 2021). 
in the playpen would be entirely unnecessary. God could simply bring it about that we freely refrain from committing horrendously evil acts, and instead have us commit just the minimum the amount of evil required for soul-making.

Theological compatibilists argue that free will is compatible with theological determinism, and that God can directly bring about the free performances of actions. Some contemporary theological compatibilists, such as Hugh McCann, think that theological determinism - unlike causal determinism-is compatible with libertarian freedom (McCann 2005, pp. 145-46). McCann even goes so far as to argue that theological determinism is a condition of libertarian freedom (McCann 2005, p. 156). Now theological incompatibilism is admittedly more popular among theists than theological compatibilism. But this seems to be largely due to the fact that incompatibilists are in a better position to address the problem of evil. 6 Theological compatibilists must explain why God did not directly bring it about that we always choose the good, given that God could easily do so without undermining creaturely freedom. In other words, theological compatibilists cannot help themselves to the free will defense. But while this may be a reason in favor of incompatibilism in the context of a debate among theists, it is not so convincing if your interlocutor is an atheist who finds the problem of evil compelling in the first place.

Even if we could identify a type of "metaphysical freedom" that is incompatible with divine determination, is this kind of freedom actually worth the amount of horrendous evil we find in the world? We have been exploring a possible scenario in which all interventions on God's part to prevent horrendous evil result—or would result-in even more horrendous evil down the road. Note that these interventions, as we have imagined them, leave at least some creaturely freedom intact. It was still open to God to prevent evil by denying creatures freedom altogether. Realizing that the counterfactuals of freedom were degenerate, God could have decided not to create any free creatures at all. If open theism is true, God may not have known ahead of time what evils would unfold. Still, God had the option to prevent further evil by simply rescinding our freedom entirely. The fact that God did not do so indicates, either that there is no God, or that a world with no metaphysical freedom and no evil is less valuable than a world that contains both.

The free will defense depends, then, on the assumption that the actual world is more valuable than a world without metaphysical freedom. This is often presented as a choice between the actual world and a world full of "innocent automata" (Mackie 1955, p. 208). That way of presenting the choice makes it seem as though creatures without metaphysical freedom would thereby lack consciousness. But this is not obviously the case. The real choice, it seems to me, is between the actual world and a world with conscious beings whose actions are directly actualized by God. While they may lack metaphysical freedom, such creatures could still have political freedom: they could still pursue good lives for themselves without interference from evildoers. If political freedom is independent of metaphysical freedom ${ }^{7}$, and if, as Sterba claims, political freedom is ultimately more valuable (Sterba 2019 , p. 12), then a world with ample political freedom but no metaphysical freedom is arguably more valuable than the actual world.

Instead of demanding why God has failed to put us in a playpen, atheologians should direct their fire towards these two assumptions at the heart of the free will defense: the claim that metaphysical freedom is incompatible with divine determination, and the claim that a world without metaphysical freedom is less valuable than the actual world. Once we grant these two principles to the free will defense, we must allow for the possibility that this is among the best of all feasible worlds: both morally perfect and even morally better worlds may be out of God's reach to create.

Funding: This research received no external funding.

Conflicts of Interest: The author declares no conflict of interest.

\footnotetext{
6 See, for example, (Hasker 2004, p. 11), or (Flint 1998, pp. 90-91).

7 Almeida argues that the two types of freedom are "logically independent" of one another (Almeida 2020, p. 246).
} 


\section{References}

Adams, Robert Merrihew. 1977. Middle Knowledge and the Problem of Evil. American Philosophical Quarterly 14: $109-17$.

Almeida, Michael. 2020. Review of J.P. Sterba, Is a Good God Logically Possible? International Journal for Philosophy of Religion 87: 245-49. [CrossRef]

Flint, Thomas. 1998. Divine Providence: The Molinist Account. Ithaca: Cornell University Press.

Hasker, William. 2004. Providence, Evil and the Openness of God. London and New York: Routledge.

Hick, John. 1981. An Irenaean Theodicy. In Encountering Evil: Live Options in Theodicy. Edited by Stephen Davis. Louisville: Westminster John Knox Press.

Kristof, Gregory. 2021. Ressurecting Mackie's Problem of Evil. Unpublished manuscript.

Lewis, David. 1993. Evil for Freedom's Sake? Philosophical Papers 22: 149-72. [CrossRef]

Mackie, John L. 1955. Evil and Omnipotence. Mind 64: 200-12. [CrossRef]

McCann, Hugh J. 2005. The Author of Sin. Faith and Philosophy 22: 144-59. [CrossRef]

Otte, Richard. 2009. Transworld Depravity and Unobtainable Worlds. Philosophy and Phenomenological Research 78: 165-77. [CrossRef]

Plantinga, Alvin. 1974. The Nature of Necessity. Oxford: Oxford University Press.

Sterba, James. 2019. Is a Good God Logically Possible? Switzerland: Palgrave Macmillan. 